\title{
THE SCIENTIFIC MOVEMENT OF STATE ISLAMIC UNIVERSITY OF IMAM BONJOL PADANG
}

\author{
Eka Putra Wirman \\ State Islamic University (UIN) Imam Bonjol Padang \\ Jl. Prof. Mahmud Yunus Lubuk Lintang Padang, West Sumatra, Indonesia \\ E-mail: ekaputrawirman@uinib.ac.id
}

\begin{abstract}
The Scientific Movement of Islamic State University of Imam Bonjol Padang. This article aims to describe the paradigm and scientific philosophy of State Islamic University of Imam Bonjol Padang that has just been transformed from State Institute for Islamic Studies (IAIN) into State Islamic University (UIN). Hence, a qualitative method is used to gather data by using documentation and interview. In addition, a focus group discussion was employed to get valid information. The result of the study indicates that the State Islamic University of Imam Bonjol adopts an interaction-dialogue paradigm. This offers every discipline to collaborate and produce integrated sciences by positioning Islam, cultures, and science as the sources of knowledge equally. Then, these three sources act together as the basis of knowledge to createbenefits for humanity.
\end{abstract}

Keyword: scientific; movement; UIN Imam Bonjol Padang.

Abstrak. Gerakan Keilmuan Universitas Negeri Islam (UIN) Imam Bonjol. Artikel ini bertujuan untuk mendeskripsikan paradigma dan filosofi keilmuan Universitas Islam Negeri Imam Bonjol Padang yang baru bertransformasi dari Institut Agama Islam Negeri (IAIN) menjadi Universitas Islam Negeri (UIN). Metode kualitatif digunakan untuk mendapatkan data dengan menggunakan teknik dokumentasi dan wawancara. Kemudian, untuk mendapatkan informasi yang valid dilakukan diskusi teman sejawat dalam bentuk focus grup discussion. Hasil Penelitian menunjukkan bahwa Universitas Islam Negeri Imam Bonjol Padang mengusung paradigma interaksi-dialogis yang memberi ruang bagi setiap ilmu untuk berinteraksi dan berdialog sehingga menghasilkan ilmu pengetahuan yang terintegrasi. Paradigma ini kemudian menawarkan setiap ilmu untuk menciptakan ilmu yang terintegrasi dengan memposisikan Islam, budaya, dan ilmu secara seimbang sebagai sumber pengetahuan. Ketiga sumber tersebut kemudian bersama-sama menjadi dasar ilmu yang bermanfaat untuk kemaslahatan masyarakat.

Kata kunci: keilmuan; gerakan; UIN Imam Bonjol Padang.

\section{Introduction}

Discourse on the dichotomy of science began to emerge as a result of the under development problem and stagnation of today's Muslims. This condition triggers the presence of various studies in order to produce the right Islamic scientific model. ${ }^{1} \mathrm{~A}$ long process has been done in order to find the formulation and basis of Islamic science which led to the way in integrating science as an offer to eliminate the dichotomy that has existed for a long time. ${ }^{2}$

Maryam Jameelah, Islam and Modernism, (Lahore: Muhammad Yusuf Khan Publisher, 1977), p. 134

${ }^{2}$ Perve Hoodhboy, Islam and Science: Religious Orthodoxy
The transition of State Islamic Insitute (IAIN/ STAIN) to Islamic State University (UIN) was the culmination of a simultaneous step in realizing the idea of integrated science. Before reaching this stage, scientists were involved in a tough debate dealing with the discourse on the dichotomy of science in Islam. ${ }^{3}$ The dichotomy which is decomposed and revealed through various dimensions and perspectives is then sought a solution by producing a scientific integration paradigm. ${ }^{4}$

\footnotetext{
and Battle for Rationality, (London: Zed Books Ltd, 1992), p. 3-6 ${ }^{3}$ Mansur, Muhammad Laili,Pemikiran Kalam dalam Islam, (Jakarta: Pustaka Firdaus, 1994), p. 76

4 Ludwig W Adamec, Histrorical Dictionary of Islam, (Lanham Marryland: Scarecrow Press, 2001), p. 9.
} 
Indeed, UIN presents as an institution of higher education which is expected to be able to respond to global competition without having to override the spirit of Islam. ${ }^{5}$ It runs on rails which in the rules of jurisprudence are termed "almuhafadzah "ala al-qadim al-shalih wa al-akhdz bi al-jadid al-ashlah" (maintaining old traditions that are still good while adapting and creating a better new traditions). It means that the transition of IAIN/STAIN status to UIN acts as a starting point as a way to integratescience.

To date, 17 IAIN/STAINs have changed their status to UIN. It was started by IAIN Syarif Hidayatullah Jakarta in 2002 and six IAINs (IAIN Mataram, IAIN Imam Bonjol Padang, IAIN Antasari Banjarmasin, IAIN Sultan Thaha Saifudin Jambi, IAIN Raden Intan Lampung, and IAIN Sultan Maulana Hasanudin Banten) which were shifted simultaneously in 2017. To maintain the equilibrium of general scientific contact and Islam in the applied science integration paradigm, each univeristy formulates the concept of science which functions as basis of scientific development. ${ }^{6}$

Based on these conditions, Rifa'i et. al ${ }^{7}$ mention two concepts of science integration as two master models that have definitively formulated scientific integration formulations and socialized them to academicians, those are the concepts of UIN Sunan Kalijaga Yogyakarta and UIN Maulana Malik Ibrahim Malang. The two models of science integration initiated by the two universities that have substantive similarities, but they differ from epistimological and operationalapplicative level. Both of these integration models are also the basis in formulating science integration models in several other UINs.

In addition to the conceptual realm of science integration, the orientation of UIN that has existed for a long time has also gradually shifted from idealism to pragmatism. This means

\footnotetext{
${ }^{5}$ Nurcholish Madjid, Khazanah Intelektual Islam, (Jakarta: Bulan Bintang, 1994), p. 65-69.

6 Sayyed Husein Nasser,Science Civilization in Islam, (Cambridge: Harvard University Press, 1968), p. 5.

7 Nurlena Rifa'i, et.al, “Integrasi Keilmuan dalam Pengembangan Kurikulum UIN Se-Indonesia: Evaluasi Penerapan Integrasi Keilmuan UIN dalam Kurikulum dan Proses Pembelajaran", Jurnal Tarbiya, Vol. 1, No. 1, June 2014. DOI: $10.15408 /$ tjems.v1i1.1108
}

that the noble goal of eliminating scientific dichotomy through the integration of general science and Islam began to be neglected due to the pragmatism of institutional development. ${ }^{8}$ UIN began to be active in analyzing market needs in determining policies related to development. One of the proofs is that there are many general scientific disciplines that are primarily needed over Islamic scientific disciplines. UIN is competing to obtain 'marketable' institution predicate by formulating some steps so that graduates can achieve the maximum degree of absorption in the community. By doing so, the existence value of UIN can continue to increase, so that budget that allocates also grow each year.

In this phase, UIN has transformed into an institution that places 'marketable' values above other ideological values; no longer focus on the destruction of the dichotomy of science, but rather a marker of pragmatism that is more concerned with the development of institutions. ${ }^{9}$ This phenomenon is certainly an important challenge responded by six UINs who have just switched their status, including UIN Imam Bonjol Padang. Therefore, this article presented and explained the scientific movement of UIN Imam Bonjol in order to face theological and pragmatic dialectics.

Related to the problems above, there are 4 relevant studies with four different points of view. Each study can be used as a basis to confirm that this study is not a replication of the previous study.

First, Mulyono ${ }^{10}$ conducted a study regarding the Model of Integration of Science and Islam in the Academic Development of UIN. This study took UIN Sunan Kalijaga Yogyakarta as an object by focusing on describing the efforts conducted by the university in integrating science and religion in order to realize scientific academic empowerment. Data was collected from

\footnotetext{
8 Netton, Ian Richard, A Popular Dictionary of Islam, (London: Curzon Press, 1992), p. 167.

9 C. W Troll, Sayyid Ahmad Khan: A Reinterpretation of Muslim Theology, (United Kingdom: Oxford University Press, 1978), p. 211.

10 Mulyono, "Model Integrasi Sains dan Agama dalam Pengembangan Akademik Keilmuan UIN". Jurnal Penelitian Keislaman, Vol. 7, No. 2, June 2011.
} 
documents in the form of works, thought, and ideas for the formation of UIN Sunan Kalijaga Yogyakarta paradigm, including: Islamic Science Integration: Meeting Islamic Epistemology and Science by Amin Abdullah (2004); Islamic Studies in the Integration-Interconnection Paradigm (An Anthology) by Amin Abdullah (2007); Restructuring the Methodology of Islamic Studies at schools in Yogyakarta by Amin Abdullah (2007); Integration of Science and Religion: Interpretation and Action by Zainal Abidin Bagir (2005). The study of texts with the qualitative descriptive method paradigm drew a conclusion that the way UIN Sunan Kalijaga endedup the scientific dichotomy and created the integration of the science of religion and science were to develop a scientific paradigm called the Integration-Interconnection paradigm by taking a metaphor of spider webs.

Second, Nurlena Rifa'i, et al" pioneered a study entitled Academic Integration of UIN's Curriculum Development in Indonesia: Evaluation of the Application of UIN Scientific Integration in Curriculum and Learning Processes. This study examined 6 UINs as research objects, like UIN Sutan Syarif Kasim, UIN Syarif Hidayatullah, UIN Sunan Gunung Djati, UIN Sunan Kalijaga, UIN Maulana Malik Ibrahim, and UIN Alauddin. This study aims to comprehensively describe the implementation of the integration of science throughout UINs in Indonesia, especially in the context of curriculum design and learning processes. This study used evaluative methods and orientations. The findings of this study indicated that the application of scientific integration concept in curriculum development, syllabus, SAP, learning process, and new academic culture was carried out by UIN Sunan Kalijaga Yogyakarta and UIN Maulana Malik Ibrahim Malang. The other four UINs are still in the normative-philosophical phase and they attempt to embody the concept of integration which was initiated into a more operational-implementative form.

Third, Lukman Hakim² analysed a study

1 Nurlena Rifa'i, et.al, “Integrasi Keilmuan dalam Pengembangan Kurikulum UIN Se-Indonesia: Evaluasi Penerapan Integrasi Keilmuan UIN dalam Kurikulum dan Proses Pembelajaran", Jurnal Tarbiya, Vol. 1, No. 1, June 2014. DOI: 10.15408/tjems.v111.1108

${ }^{12}$ Lukman Hakim. "Quo Vadis Pengembangan Keilmuan on Quo Vadis Scientific Development in UIN: Secularization or Quranic Knowledge. This study investigated an ideal formulation of UIN scientific development based on ambiguity raised by several circles in understanding the direction of the development of IAIN that has been converted into UIN. There were pros and cons that exist around the flexibility of UIN scientific paradigm, so it can be drawn towards quranization of science or secularization. In order to anticipate the worst possibility that could threaten the scientific paradigm of UIN, reviewers offered engineering blueprints for UIN scientific development to revitalize positive values and reduce the negative side that will emerge.

Fourth, Zainal Arifin ${ }^{13}$ did a study entitled Integrative Scientific Development at the State Islamic University. Research based on Islamic scientific development tried to analyze and interpret integrative scientific development in UIN Sunan Kalijaga Yogyakarta and UIN Maulana Malik Ibrahim Malang in terms of its relevance to the development of postmodernism philosophy. The integrative scientific development of UIN Sunan Kalijaga model in Yogyakarta and UIN Maulana Malik Ibrahim Malang is based on the basis of the epistemology of integrated scientific development between strong science and Islam. One reflection of integrative scientific development in the two UINs is the opening of general scientific faculties e.g. Science and Technology, Sociology, and Psychology. The conversion represents a new relationship between general science and Islam in the form of a relationship of mutual needs, mutual dialogues, and mutually reinforcing in solving various problems in human life.

The differences among four studies in this article can be seen in the intensity of the problem and the focus of the study. From the aspect of the problems, the studies above highlight the dimensions of the integration of science and religion, scientific integration as a spirit of curriculum development, solution finding to

UIN: Sekularisasi atau Quranisasi Ilmu Pengetahuan”. Jurnal Substantia, Vol. 16, No. 1, April 2014.

13 Zainal Arifin, "Pengembangan Keilmuan Integratif di Universitas Islam Negeri”. Jurnal Insania, Vol. 19, No. 2, JulyDecember 
misunderstandings regarding status switching, and the integrative scholarly development style in UIN. This article focused on scientific paradigm and movement issues which were formulated by UIN Imam Bonjol in order to realize the integration of science and the elimination of the dichotomy of science which was clashed with the interests of pragmatism in the development of institutions. As a result, this article aims to explain the formulation of integrated-science at UIN Imam Bonjol which is required to be consistent with khittah and must respond to various pragmatic demands.

\section{Method}

This study is a field research using a descriptive qualitative method by collecting data until it achieves the maximum degree of validation and conveying the results of the analysis in detail and depth ${ }^{14}$. The data of this study are in the form of policies, regulations, and agreements obtained from written documents and oral utterances related to the scientific movement of UIN Imam Bonjol in facing theological and pragmatic dialectics. The data sources in this study are documents, conceptors, and managers of Imam Bonjol Padang State Islamic University.

Data was collected through documentation techniques, interviews, and focus group discussions (FGD). Documentation techniques were used in order to find data about policies, regulations, and agreements contained in written documents. The interview technique was conducted to obtain data related to planning, implementation, and management processes in the context of its efforts to integrate general science and Islam. Focus group discussion (FGD) technique was also conducted to confirm and verify documentation findings and interview data. In order to validate all data that had been collected, the analysis is truly searched for a valid data.

Data analysis was conducted by following some stages stated by Miles and Huberman ${ }^{15}$

${ }^{14}$ Nana Syaodih Sukmadinata, Metode Penelitian Pendidikan, (Bandung: Remaja Resdakarya, 2007), p. 59.

${ }^{15}$ Mathew Miles, B dan Michael Huberman, Qualitative Data Analysis, (Trans. Jakarta: UI Press, 2005), p. 79. called data reduction, data presentation, and drawing conclusion. Data validity test was done by triangulation and peer discussion techniques proposed by Moleong ${ }^{16}$.

\section{Paradigm of UIN Imam Bonjol's Knowlegde}

UIN Imam Bonjol Padang has three transformation loci which at the same time becomesa place to transform the spirit of transition statusfrom IAIN to UIN. The actual problems that exist on each of these loci are the determinants of the scientific paradigm that is carried out. Therefore, it is important to present a glimpse of the three loci before describing the scientific paradigm as a result of the long process that the drafting team went through.

The first locus is the world that brings the problems collectively at the global level. The rapid flow of globalization has an impact on all lines of life, including education. In this context, globalization influences three important elements; economy, politics, and policy. In the economic aspect, globalization has created a shift in the goal of education in higher education which originally served to produce educated and capable human resources to enlighten the problems faced by society. It also functions in preparing them to work, so that they are trained based on the the field needs. In the political aspect, educational institutions are required to be able to negotiate and build cooperation with other institutions in order to maintain their existence. In the aspect of policy, the economy and politic that were brought about by the era of globalization are important determinants as a policy maker in universities.

The second locus is Indonesia as a part of the world. Decentralization and democratization leave urgent problems in the community. The problem can be cause by the unpreparedness of the community to accept progress that grows so fast. Freedom of opinion provides a broad space for parties who were previously marginalized to be able to speak out loud. On the basis of technological sophistication as a medium of

${ }^{16}$ Lexy J Moleong, Metodologi Penelitian Kualitatif, (Bandung: Remaja Resdakarya, 2007), p. 31. 
delivery, vertical and horizontal conflicts are very vulnerable to occur. This phenomenon is a challenge for gaining unity and diversity of anation. Educational institution as one of the elements in this situation is expected to contribute and take a role in addressing these issues.

The third locus is West Sumatra as a local place. As the smallest locus, the problems caused by the flow of globalization can be clearly observed. Local problems are more directed at the problem of identity. People of West Sumatra that has a specific culture and character are diminished and alienated by the external culture that come easily and rapidly. This phenomenon makes the existing identity blurred and contaminated. The community began to melt in the flow of global culture which often differed even contrary to the principles of local culture that had been adopted. Therefore, identity voicing also becomes vague and ambiguous. It comes from voiced identities that are adopted from global media that has a different sociocultural background from reality in the local context.

In addition, the constellation of scientific dialectics that is currently existed has become an important consideration. It cannot be denied that the scientific scholars of Islam and modern Western technology are two entities that are always confronted in avis a visway. Islamic scholarship is used as an intrinsic identity which-intentionally or not-is not treated fairly by Muslim scientists. Some groups of scientists do not practice the developmental principle, so classical Islamic scholarship does not understand it as a dynamic and constantly evolving reality. On the contrary, there is a group of scientists that feel sophisticated of modern technology but they begun to forget the noble values of classical Islamic scholarship. Therefore, these two things in fact of having fallen behind in the next step.

Based on this situation, UIN Imam Bonjol Padang presents scientific spirit in strengthening the classical Islamic scientific tradition by accommodating modern Western science. This method is a strategic step in reconciling the two things that are always contested. The drafting team tries to design scientific concepts which later can put Islam and Western in an ideal position, not overlapping one another.

In order to follow up on this vision, a review of Minangkabau culture and locality values was carried out as the locus of the existence of UIN Imam Bonjol Padang. The drafting team found that the reality of Minangkabau people who were filled with noble values as a reference in living their lives was influenced by three principal circumstances. The first is Islam. Islamic values become the spirit of Minangkabau community of which the community must be muslim. Islam and Minangkabau are two components that are always identified and involved.The secondis a culture. Minangkabau community hasa famous cultural custom that has been constantly upheld by society. Cultural customs that exist in their life shapes the character of Minangkabau community. The third is science. The existence of the Dutch in Minangkabau history created a modern science that influenced the existence of Minangkabau people.

Based on this condition, UIN Imam Bonjol Padang positioned Islam, culture, and science as three inspirations and sources in the process of producing knowledge. The three elements are put parallel without any dominant position from each other. UIN Imam Bonjol Padang believes that prioritizing one element compared to other elements in the scientific paradigm will actually create a new dichotomy space for the existing scienceseven in a fiercer form than before.

UIN Imam Bonjol Padang carries scientific paradigm of Interaction-Dialogue. It is the principle and point of view of this university Padang towards various disciplines by providing an area to interact and dialogue between these sciences. Similar to integration, the dialogue model also refers to the typology of the relation between science and religion proposed by Barbour (1997). This university chose a model of dialogue, not integration, because in fact integration that unites two or more elements in one medium would reinforce the dominance of one element and legitimize the marginalization of other elements (in this case the elements are science, religion, etc.). The dialogue model is seen as more accommodating to the reality 
of the independence of a science, so that it can still maintain its identity and characteristics when dealing with other sciences.

In this context, Islam will be given a place to interact with culture and science, and vice versa. The three elements bound to each other so that a new knowledge emerges whose form cannot be determined at the beginning. ${ }^{17}$ In these interactions and dialogues, each element cannot impose truth claims on other elements. All three appreciate each other's style of approach used in assessing a reality. The Interaction-Dialogical Paradigm requires the methodological tool in the form of in-depth study of the tangent points between the three elements where the methodological similarities and differences between the two are located.

Philosophically, the paradigm of dialogical interaction departs from the ontological reality which is plural in nature. The reality faced by academic society element is always multidimensional. Dealing with science based on the multidimensional reality of this reality has been emphasized for thousands years. The fact of an objective-empirical nature has given birth to natural science as an instrument of approach; reality in the form of relations and exchanges between humans and between humans and nature has formed social science as a tool of study; the reality in human subjective-experience itself has built the humanities as a research perspective. With the plural ontological reality, humans cannot face the full and absolute reality. Thus, UIN Imam Bonjol Padang adheres to the ontology of pluralism, not monism. ${ }^{18}$

The ontology pluralism automatically has implications for the epistemological aspects and methodologies that will be used as the basis of development. Multiple ontologies formed a pluralistic epistemology. The epithemology of bayani, ifrani, and burhani which was famous in the golden age of Islam or empiricism, rationalism, and pragmatism in Western philosophy was positioned in an academic community (commuter)

17 Jamal Al-Din Al-Afghani, Al-Radd 'ala Al-Dahriyin. Trans. Muhammad Abduh., (Mesir: Mathba'ah Al-Rahmaniyah, 1925), p. 139

${ }_{18}$ Proposal of UIN Imam Bonjol Padang, 2016, p. 31 which jointly sought the truth. The same thing applies to the methodology. The object of study in the form of text, social relations, and individual subjective experiences is assessed using the right method for each object. ${ }^{19}$

The ontology and epistemology patterns ultimately have implications for the axiological aspect. With the reality of plurality of reality that must be approached by multiple methods and methods, axiological pluralism is born at the level of value consideration. At this point, UIN Imam Bonjol Padang's axiomatic paradigm is axiological pluralism. Values in humans can come and be chosen from a variety of sources due to interactions that they do with humans and other cultures. Thus, human beings are interrelated with each other in their consideration of values. ${ }^{20}$

The style of pluralism that exists in all three philosophical elements is based on the basic principles of Minangkabau culture, "balance in opposition". This principle provides a solution to overcome the reality of pluralism. As Nasroen ${ }^{21}$ stated, conflict is a common thing that cannot be overcome by dialectics and integration. Both methods are not effective for reconciling conflicting things. Contradictions can be resolved by the active movement of balancing carried out by humans as actors in reality. By balancing, the substance that exists in all-plural reality remains and is maintained. These conflicting realities interact with each other and dialogue with each other to realize the benefit of being in the common interest.

The style of pluralism that exists in all three philosophical elements is based on the basic principles of Minangkabau culture, "balance in opposition". This principle provides a solution to overcome the reality of pluralism. As Nasroen ${ }^{22}$ stated, conflict is a common thing that cannot be overcome by dialectics and integration. Both methods are not effective for reconciling conflicting things. Contradictions can be resolved by the active movement of balancing conducted

\footnotetext{
${ }^{19}$ Proposal of UIN Imam Bonjol Padang, 2016, pp. 31-32

${ }^{20}$ Proposal of UIN Imam Bonjol Padang, 2016, pp. 31-32

${ }^{21}$ Nasroen, M, Dasar Falsafah Adat Minangkabau, (Jakarta: Bulan Bintang, 1959).

${ }^{22}$ Nasroen, M, Dasar Falsafah Adat ....
} 
by humans as actors in reality. By balancing, the substance that exists in all-plural reality remains and is maintained. These conflicting realities interact with each other and dialogue with each other to realize the benefit of being in the common interest.

To realize the concept of balance in the contradictions taken through interaction and dialogue, UIN Imam Bonjol Padang created a new rethoric model proposed by Perellman as an implementation paradigm..$^{23}$ Rhetoric is interpreted as an effort to find the means of persuasion in arguing, recognizing acceptable models of persuasion in a discourse, and formulating persuasive values from the arguments raised. ${ }^{24}$ Rhetoric which has the substance of the meaning of respecting arguments by means of carrying out persuasion becomes the door and the starting point for the realization of balance in opposition. Through this pattern, efforts to reconcile existing contradictions are not manifested in "raw fights" arguments that overtake each other, but are in persuasion whose principles are mutually constructive.

In its concrete form, the new rhetorical model as an implementation paradigm is in the form of dialogue between one scientific discipline and another about the same reality. Science disciplines, with their respective perspectives, put forward their arguments regarding this reality. The end of the argument is the conclusion of each discipline in the form of support or rejection of the perspective of other disciplines applied in persuasive patterns. Persuasive patterns that do not rely on coercion of arguments will manifest adult attitudes on the elements of the academic community. Other disciplinary perspectives must be accepted if they are true, and the perspective of the disciplines themselves must be available to be criticized if in the process of dialogue with other disciplines found gaps in methodological defects and scientific work techniques.

Thus, the main requirement that the elements of the academic community must have as agents or active actors of the dialogue is the paradigm of "serving the truth". Academicians must minimize

\footnotetext{
23 Proposal of UIN Imam Bonjol Padang, 2016, p. 34
}

24 Proposal of UIN Imam Bonjol Padang, 2016, p. 34 the fanaticism in their respective disciplines. A good understanding of the position of the discipline itself in assessing reality is important, because that is why an academic can understand why the conclusions he produces can differ from conclusions produced by other disciplines. In addition, the academics must also have good self-evaluation skills. One consequence of the interaction with the subject in other disciplines is the opening of a gap in the weakness of his own argument, and as an academic person, he must be prepared to criticize himself for these shortcomings.

\section{Metaphor of An-Nahl in UIN Imam Bonjol's Knowledge}

To simplify, UIN Imam Bonjol Padang chose the An-Nahl (bee and honeycombs) metaphor as an embodiment of the scientific paradigm applied. The metaphor can be seen in the following picture:

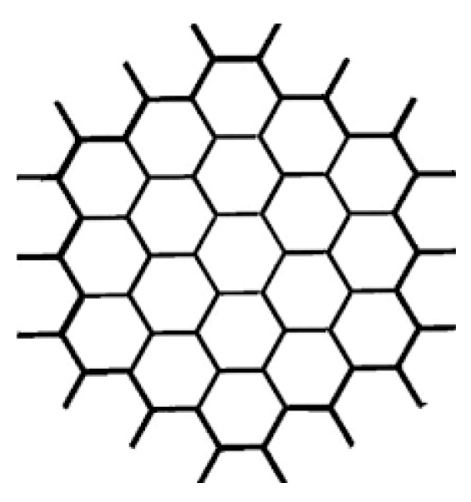

In An-Nahl (bee and honeycombs) metaphor, each bee has its own nest which it manages personally and independently. ${ }^{25}$ Each bee does not interfere with the business of bees in other nests, and it only focuses on working on the nest. This metaphor describes the way of scientific work in the perspective of UIN Imam Bonjol Padang. Each science has independence and independence that other sciences cannot interfere with. Each science is accommodated to explain phenomena and reality from its perspective, and not interfere with each other's academic activities in other disciplines. ${ }^{26}$

${ }^{25}$ Al-Bahi, Al-Fikr Al-Islami Al-Hadith wa Silatuhu bi AlIsti'mar Al-Arabi (Mesir: Maktabah Al-Wahbah, 1960), p. 143.

${ }^{26}$ Maryam Jameelah, Modern Technology and Dehumanization of Man, (Lahore: Al-Mathba'ah Al-Arabiyah, 1983), p. 110 
Even though they have their own spaces in a rectangular shape, all the honeycombs are integrated into one unit. All nests are integrated, but the boundary between one nest and another can be confirmed. Each nest unites without having to melt one nest with another. In the context of the Imam Bonjol Padang UIN scientific paradigm, honeycomb integration illustrates interaction and dialogue between various disciplines. Social, natural, and humanities can interact and dialogue with each other regarding a phenomenon, but the interaction and dialogue does not necessarily eliminate the identity and character of each of these sciences. Each science remains independent with the perspectives and conclusions that have been produced. The interaction and dialogue activities provide space to enrich and evaluate the perspectives of each science, so that the conclusions produced can reach a higher degree of comprehension.

Bees that work in their booths and are integrated with bees in other booths have the same purpose and orientation e.g. to produce honey. Despite having different booths, the work of each of these bees is unified: making honey, which has many benefits and is beneficial for life. This situation illustrates the perspective of UIN Imam Bonjol Padang on the scientific work of various existing disciplines. All disciplines that have methodological characteristics and their respective scientific work steps will ultimately contribute to their work to realize the benefit of society. The scientific work of UIN Imam Bonjol Padang, which has undergone a process of interaction and dialogue between these sciences, is Islam which means that science which was born from an effort to establish a balance in the opposition of each science. Islam in the scientific context of Imam Bonjol UIN Padang is what makes Islam, culture and science a source of inspiration in producing knowledge.

In the honeycomb metaphor, the outermost part of the structure of the honeycomb surface is deliberately left open. This means that the nest can be expanded to become infinitely larger. This reflects the perspective of UIN Imam Bonjol Padang on the development and dynamics of science. With continuous scientific work and a reality that is constantly changing from time to time, science will always expand to a limit that cannot be measured. With the opening of the outermost structure of the honeycomb surface, the meaning is that UIN Imam Bonjol Padang will be ready to accommodate the development of science, whatever extent will be. UIN Imam Bonjol Padang does not want to limit development and dynamism, as stated in one Minangkabau proverb: Sakali aia gadang, sakali tapian barubah (the flow changes the river all at once). So, there is no science that is static and stagnant.

The six elements/sub-elements exist in the inner and zahir elements formed a hexagonal scientific basic framework of Imam Bonjol Padang State Islamic University, which can be called an Islamic scientific framework. The sub-elements interact with each other until finally they produce the elements forming each sub-element. The dialectics of each sub-element that gives birth to the elements forming each element can be seen in the following figure:

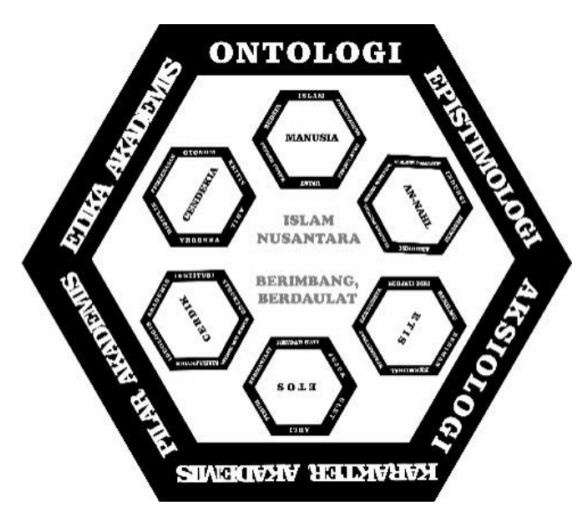

From the framework of Islamic hexagonal of UIN Imam Bonjol Padang, it can be seen that the ontology side rests on humans. Here, any reality, categorized in any way, still rests on humans. ${ }^{27}$ Humans experience the dialectic between subject and reality. As part of the community, he dialectically with Islam which is a religious identity that he adheres to. As a citizen, human has dialectics with science which in this case is identified with Western civilization. As a cultural follower, he interacts with the culture in his environment.

The Islamic epistemology side rests on the

\footnotetext{
${ }^{27}$ Proposal of UIN Imam Bonjol Padang, 2016, p. 37
} 
mechanism of the work of bees (An-Nahl). As stated earlier, bees work individually as well as together, individualists and communalists. ${ }^{28}$ The mechanism of work of the bees is an inspiration that the way Islamic science works is to seek knowledge independently based on their respective disciplines in order to realize a common goal. The method of scientific work also experiences dialectic between two elements called reality and reasoning. Reality is in the form of factual nature in dialectics with inductive reasoning models. The reality is conceptual reality in dialectics with an inductive reasoning model. Reality is in the form of imaginative reality dialectically with abductive reasoning model.

The side of Islamic scientific axiology rests on ethical principles. ${ }^{29}$ Ethics is a value that reflects Islamic scientific identity. As a cornerstone of the axiology, ethics also consists of two elements that are mutually interconnected. These two elements are the values and traits inherent in the Islamic practicing person. Moral values are inherent in an academic with the nature of identity. The value of faith that is inherent in an academic with dialectics with a cultural nature. The value of knowledge in an academic has a dialect with dignity.

The dialectic of the two elements on the axiological side also forms a hexagonal called hexagonal Islamic scientific axiology. The hexagonal can be seen in the following picture.

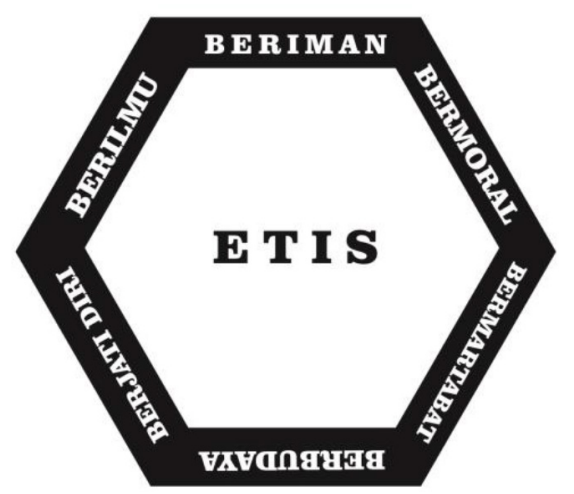

The academic character rests on the ethos..$^{30}$ It means that Islamic scholarship emphasizes the

\footnotetext{
${ }^{28}$ Proposal of UIN Imam Bonjol Padang, 2016, p. 39

29 Proposal of UIN Imam Bonjol Padang, 2016, p. 39

30 Proposal of UIN Imam Bonjol Padang, 2016, p. 39
}

character of academics that have a high ethos of learning and work. Ethos is the basic foundation underlying scientific activities conducted by academics within the scope of Islamic scholarship. As an academic character, ethos is the result of dialectic between two elements of character and character. Expertise as a dialectic character with humility. Firmness as a dialectic character with honesty. Tenacity as a dialectic character with beneficial qualities.

The dialectics of the two elements on the side of the academic character also forms a hexagonal called hexagonal Islamic academic character. The hexagonal can be seen in the following picture.

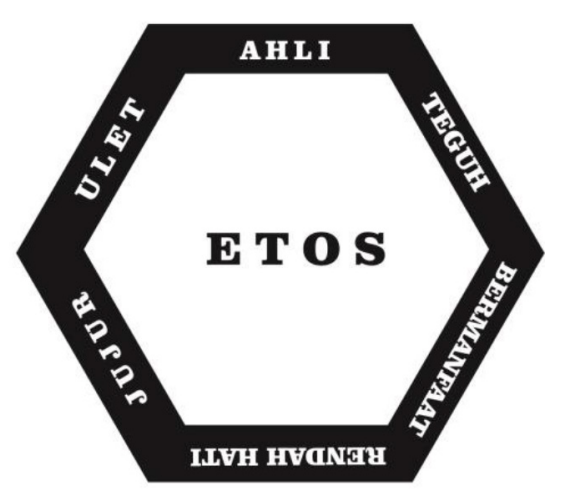

The academic pillar rests on the ingenuity and creativity of an academic. ${ }^{31}$ Cleverly becomes a pillar or catalyst that moves an academic in Islamic scholarship. Cleverly can mean wise and full of wisdom, namely a condition in which an academic can respond to various things appropriately and effectively. Cleverly also means that an academic can observe and read the situation well, so that he is able to make informed decisions in acting. As an academic pillar, clever is the result of dialectic between two elements, called mind and zahir. Academic dialectics with human resources. Ideology of dialectics with infrastructure. Management interacts with institutions.

The dialectic of two elements on the academic pillar also forms a hexagonal called hexagonal academic pillar of Islamic science. The hexagonal can be seen in the following picture.

${ }^{31}$ Proposal of UIN Imam Bonjol Padang, 2016, p. 40 


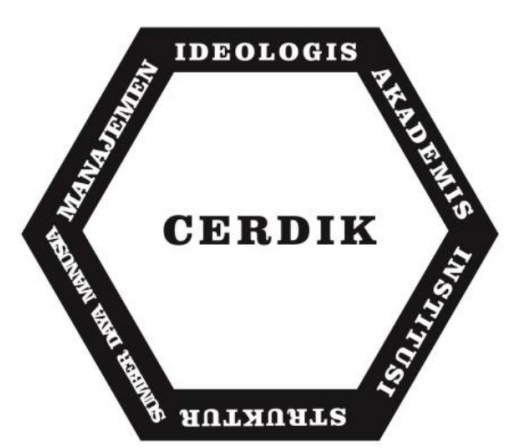

Academic ethics rests on scholarship. ${ }^{32}$ I means that academics in the scientific concept of Islam are intelligent and master their scientific fields. Good mastery in the scientific field is what makes an academic can be independent and independent in carrying out scientific work activities. As academic ethics, scholars are the result of dialectic between two elements, namely ideology and system. Freedom which becomes the ideology of academic work with dialectics with justice which is the spirit of the system. Critical attitude that becomes a scientific characteristic of dialectics with discipline as one of the elements of the system. Autonomy as a dialectical academic character with openness as the impact of the system.

The dialectics of the two elements on the side of academic ethics also forms a hexagonal concept called Islamic academic hexagonal ethics. The hexagonal can be seen in the following picture.

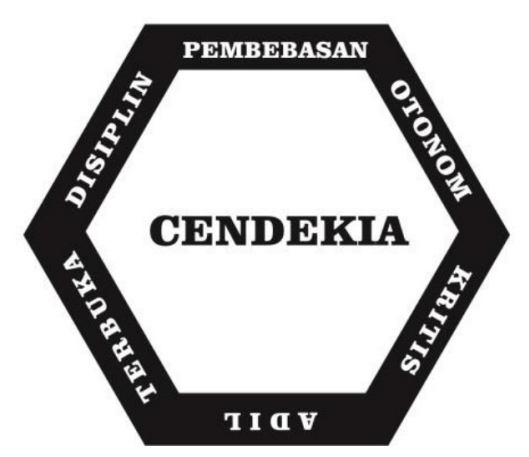

From the description of the philosophy of the scientific paradigm of An-Nahl (bees and honeycombs) which produces Islamic scientific models, it can be concluded that in fact the

${ }^{32}$ Proposal of UIN Imam Bonjol Padang, 2016, p. 40 elements in the paradigm are a form of balance of two conflicting elements. UIN Imam Bonjol Padang applied the Wasathiyah value which was defined as an effort to balance the reality of pluralism that surrounds humans. In addition, An-Nahl paradigm also emphasizes the principle of sovereignty in the academic community when faced with such opposition. This sovereignty is defined as its independence in carrying out scientific activities in their respective scientific fields.

\section{Scientific typology in UIN Imam Bonjol}

The response of Muslim scientists to the development of general science is an important point that becomes the root of the discourse of the integration of science. ${ }^{33}$ Various criticisms that were raised to the arena of academic debate to produce specific ideas and theories also enlivened the discourse struggle which was packaged in the momentum of efforts to revive Islamic education which was considered to have lagged far behind. ${ }^{34}$ The response is a reflection of academic awareness and anxiety among Muslim scientists, so that the spirit of change can be echoed in the realm of global Islamic education. ${ }^{35}$

If in the study of civilization locus known as Hassan Hanafi, through the 'tradition and renewal' project of al-wa wa-tajdid introduces al-istigrab oxidentalism in an attempt to undermine Western domination of the East, and divide the attitude of Muslims towards classical traditions type of shilah al-inqitha discontinuation and shilah al-ittishal interconnection 'which is directly proportional to their response to Western civilization, ${ }^{36}$ then in the realm of science also found experts who formulated the typology of response of

33 Mona Abaza, "Some Reflections on the Question of Islam and Social Sciences in the Contemporary Muslim World," Social Compass 40, No. 2, 1993, pp 301-321; Bassam Tibi, "Culture and Knowledge: The Politics of Islamization of Knowledge as a Postmodern Project? The Fundamentalist Claim to de-Westernization," Theory, Culture \& Society 12, No. 1, 1995, pp. 1-24.

34 Abu Al-A'la Maududi, Khilafah dan Kerajaan: Evaluasi Kritis atas Dasar Sejarah Pemerintahan Islam. Transj. Muhammad Al-Baqir, (Bandung: Mizan, 1993), p.190.

35 Mahmud Husain, A History of Freedom Movement, (Karachi: Pakistan Historical Society, 1975), p. 241.

${ }^{36}$ Hanafi, Hassan, Muqaddimah fi Ilm Al-Istighrab, (Kairo: Dar Al-Fanniyah, 1991), pp. 14-15 
Muslim scientists to general science. These experts map the developing discourse, both in the philosophical-paradigmatic and operationalapplicative domains.

The typologies that are born later will be able to make a great contribution in order to understand the various styles of integration of religious and general sciences that exist and are always dynamic. For this reason, the following is explained by several experts who formulated the typology of Muslim scientists' responses to the general science. ${ }^{37}$ The dialogical interaction paradigm which is the basic concept of formulating the scientific movement of UIN Imam Bonjol is in line with the ideas introduced by Hoodhboy. ${ }^{38}$ It means that the formulation of the scientific movement of UIN Imam Bonjol is in the frame of Muslim scientific typology as stated by Hoodhboy.

The paradigm of interaction-dialogue offers Quran and hadith as inspiration and a source for Islamic scholarship. Paradigm that places Islam, culture, and science as a trilogy in producing knowledge is in line with Ali's point of view. ${ }^{39}$ The similarity of the flow can be seen from the paradigm proposed by UIN Imam Bonjol that each science has its own independent and unique characteristics, while Ali in a cross-disciplinary study also emphasizes that the characteristics of each science entity must be placed in a complementary frame rather than claiming each other as the most correct.

\section{Conclusion}

UIN Imam Bonjol Padang implements the scientific paradigm of dialogical interaction that holds integrated-science. This leads to the

37 Pam Hanley, Judith Bennett, and Mary Ratcliffe, "The Inter-Relationship of Science and Religion: A Typology of Engagement," International Journal of Science Education 36, No. 7 2014, pp 1210-1229; Stefano Bigliardi, "Barbour's Typologies and the Contemporary Debate on Islam and Science," Zygon 47, No. 3, 2012, pp. 501-519; Zainal Abidin Bagir, "Islam, Science, and 'Islamic Science': How to 'Integrate'Science and Religion,” Science and Religion in a Post-Colonial World. Interfaith Perspectives, 2005, 37-61; Zainal Abidin Bagir, "Practice and the Agenda of "Islam and Science,"” Zygon ${ }^{\circledR} 47$, No. 2, 2012, pp. 354-366.

${ }^{38}$ Perve Hoodhboy, Islam and Science: Religious Orthodoxy and Battle for Rationality. London: Zed Books Ltd, 1992, p. 55.

${ }^{39}$ Ali, Sayyid Amir, The Spirit of Islam. London: Christophers, 1955, p. 183 dominance among sciences that subsequently will create a new dichotomy. In relation tothis situation, the paradigm of dialogical interaction offers a model of dialogue among sciences without really collecting these sciences. They are given the freedom to work independently and dialogue with other sciences to enrich perspectives related to the knowledge he has produced. Hence, Interactive dialogue between the sciences will produce new knowledge.

The paradigm of dialogic interaction positions Islam, cultures, and science equally in its capacity as the sources of knowledge. The three sources also interact and act as the basisof knowledge in order to create the benefit for the humanity. UIN Imam Bonjol Padang has adopted honeycomb as a metaphor that illustrated his scientific paradigm. Honeycomb illustrates the independent workings of each nest without participating and interfering with the work of bees in other nests. However, all bees work together to produce honey which means that the science is independent, but it still interconnected in producing knowledge.

\section{References}

Abaza, Mona. "Some Reflections on the Question of Islam and Social Sciences in the Contemporary Muslim World." Social Compass 40, No. 2, 1993.

Adamec, Ludwig W,Histrorical Dictionary of Islam. Lanham Marryland: Scarecrow Press, 2001. Afghani, Jamal Al-Din, Al-, Al-Radd 'ala Al-Dahriyin. Terj. Muhammad Abduh. Mesir: Mathba'ah Al-Rahmaniyah, 1925.

Ali, Sayyid Amir, The Spirit of Islam. London: Christophers, 1955.

Badawi, Muhammad Zaki,The Reformers of Egypt: A Critique of Al-Afghani, Abduh, And Ridha. Slough: The Open Press, 1976.

Bagir, Zainal Abidin. "Islam, Science, and 'Islamic Science': How to 'Integrate'Science and Religion." Science and Religion in a PostColonial World. Interfaith Perspectives, 2005. _- "Practice and the Agenda of "Islam and Science."” Zygon ${ }^{\circledR}$ 47, No. 2, 2012.

Bigliardi, Stefano. "Barbour's Typologies and the Contemporary Debate on Islam and Science." Zygon ${ }^{\circledR}$ 47, No. 3, 2012. 
Haqqani, Husein,Pakistan Between Mosque and Military. Washington: Carnegie Endowment for International Peace, 2005.

Hanafi, Hassan, Muqaddimah fi Ilm Al-Istighrab. Kairo: Dar Al-Fanniyah, 1991.

Hoodhboy, Perve,Islam and Science: Religious Orthodoxy and Battle for Rationality. London: Zed Books Ltd, 1992.

Hanley, Pam, Judith Bennett, and Mary Ratcliffe. "The Inter-Relationship of Science and Religion: A Typology of Engagement." International Journal of Science Education 36, no. 7, 2014.

Husain, Mahmud, A History of Freedom Movement. Karachi: Pakistan Historical Society, 1975.

Jameelah, Maryam, Islam and Modernism. Lahore: Muhammad Yusuf Khan Publisher, 1977.

Lukman Hakim. "Quo Vadis Pengembangan Keilmuan UIN: Sekularisasi atau Quranisasi Ilmu Pengetahuan". Jurnal Substantia, Vol. 16, No. 1, April 2014.

- Modern Technology and Dehumanization of Man. Lahore: Al-Mathba'ah Al-Arabiyah, 1983.

Madjid, Nurcholish,Khazanah Intelektual Islam. Jakarta: Bulan Bintang, 1994.

Mansur, Muhammad Laili,Pemikiran Kalam dalam Islam. Jakarta: Pustaka Firdaus, 1994.

Maududi, Abu Al-A'la,Khilafah dan Kerajaan: Evaluasi Kritis atas Dasar Sejarah Pemerintahan Islam. Terj. Muhammad Al-Baqir. Bandung: Mizan, 1993.

Miles, Mathew. B dan Michael Huberman,Qualitative Data Analysis. Terjemahan. Jakarta: UI Press, 2005.
Moleong, Lexy J,Metodologi Penelitian Kualitatif. Bandung: Remaja Resdakarya, 2007.

Mulyono, "Model Integrasi Sains dan Agama dalam Pengembangan Akademik Keilmuan UIN". Jurnal Penelitian Keislaman, Vol. 7, No. 2, June 2011.

Nasroen, M,Dasar Falsafah Adat Minangkabau. Jakarta: Bulan Bintang, 1959.

Nasser, Sayyed Husein,Science Civilization in Islam. Cambridge: Harvard University Press, 1968.

Netton, Ian Richard, A Popular Dictionary of Islam. London: Curzon Press, 1992.

Nurlena Rifa'i, dkk, “Integrasi Keilmuan dalam Pengembangan Kurikulum UIN SeIndonesia: Evaluasi Penerapan Integrasi Keilmuan UIN dalam Kurikulum dan Proses Pembelajaran",Jurnal Tarbiya, Vol. 1, No. 1, June 2014. DOI: 10.15408/tjems.v111.1108

Sukmadinata, Nana Syaodih, Metode Penelitian Pendidikan. Bandung: Remaja Resdakarya, 2007.

Tibi, Bassam. "Culture and Knowledge: The Politics of Islamization of Knowledge as a Postmodern Project? The Fundamentalist Claim to de-Westernization." Theory, Culture \& Society 12, No. 1, 1995.

Troll, C.W, Sayyid Ahmad Khan: A Reinterpretation of Muslim Theology. United Kingdom: Oxford University Press, 1978.

Zainal Arifin, "Pengembangan Keilmuan Integratif di Universitas Islam Negeri”. Jurnal Insania, Vol. 19, No. 2, July-December 